\title{
Workshop report on hard-rock drilling into mid-Cretaceous Pacific oceanic crust on the Hawailian North Arch
}

\author{
Tomoaki Morishita $^{1,2}$, Susumu Umino ${ }^{1}$, Jun-Ichi Kimura ${ }^{3}$, Mikiya Yamashita ${ }^{4,5}$, Shigeaki Ono ${ }^{3}$, \\ Katsuyoshi Michibayashi ${ }^{6}$, Masako Tominaga ${ }^{7}$, Frieder Klein ${ }^{8}$, and Michael O. Garcia ${ }^{9}$ \\ ${ }^{1}$ School of Geosciences and Civil Engineering, College of Science and Engineering, \\ Kanazawa University, Kanazawa, Ishikawa 920-1192, Japan \\ ${ }^{2}$ Lamont-Doherty Earth Observatory, Columbia University, New York, NY 10027, USA \\ ${ }^{3}$ Volcanoes and Earth's Interior Research Center, Research Institute for Marine Geodynamics, Japan Agency for \\ Marine-Earth Science and Technology (JAMSTEC), 2-15 Natsushima, Yokosuka, Kanagawa 237-0061, Japan \\ ${ }^{4}$ Tectonics and Resources Research Group, Research Institute of Geology and Geoinformation, National \\ Institute of Advanced Industrial Science and Technology (AIST), 1-1-1 Higashi, \\ Tsukuba, Ibaraki 305-8567, Japan \\ ${ }^{5}$ Subduction Dynamics Research Center, Research Institute for Marine Geodynamics (IMG), Japan Agency for \\ Marine-Earth Science and Technology (JAMSTEC), 3173-25, Showa-machi, \\ Kanazawa, Yokohama, Kanagawa 236-0001, Japan \\ ${ }^{6}$ Department of Earth Planetary Sciences, Graduate School of Environmental Studies, Nagoya University, \\ Nagoya 464-8601, Japan \\ ${ }^{7}$ Department of Geology and Geophysics, Woods Hole Oceanographic Institution, \\ Woods Hole, MA 02543, USA \\ ${ }^{8}$ Department of Marine Chemistry and Geochemistry, Woods Hole Oceanographic Institution, \\ Woods Hole, MA 02543, USA \\ ${ }^{9}$ Department of Earth Sciences, University of Hawai'i i at Mānoa, Honolulu, HI 96822, USA
}

Correspondence: Tomoaki Morishita (tomo_make_a_wish@icloud.com)

Received: 14 April 2019 - Revised: 22 July 2019 - Accepted: 15 August 2019 - Published: 2 December 2019

\begin{abstract}
The architecture, formation, and modification of oceanic plates are fundamental to our understanding of key geologic processes of the Earth. Geophysical surveys were conducted around a site near the Hawaiian Islands (northeastern Hawaiian North Arch region; Hawaiian North Arch hereafter), which is one of three potential sites for an International Ocean Discovery Program mantle drilling proposal for the Pacific plate that was submitted in 2012. The Hawaiian North Arch site is located in 78-81 Ma Cretaceous crust, which had an estimated full spreading rate of $7-8 \mathrm{~cm} \mathrm{yr}^{-1}$. This site fills a major gap in our understanding of oceanic crust. Previously drilling has been skewed to young or older crust $(<15$ or $>110 \mathrm{Ma})$ and slow-spread crust. P-wave velocity structure in the uppermost mantle of the Hawaiian North Arch shows a strong azimuthal anisotropy, whereas Moho reflections below the basement are variable: strong and continuous, weak, diffuse, or unclear. We assume that the strength of the Moho reflection is related to the aging of the oceanic plate. The Hawaiian volcanic chain ( $200 \mathrm{~km}$ to the southwest of the proposed drill site) and the nearby North Arch magmatism on the proposed Hawaiian North Arch sites might also have affected recognition of the Moho via deformation and/or magma intrusion into the lower crust of the uppermost mantle. This workshop report describes scientific targets for $2 \mathrm{~km}$ deep-ocean drilling in the Hawaiian North Arch region in order to provide information about the lower crust from unrecovered age and spreading rate gaps from previous ocean drillings. Other scientific objectives to be achieved by drilling cores before reaching the target depth of the project are also described in this report.
\end{abstract}


1

\section{Introduction}

The architecture of oceanic plates is the fundamental question for understanding why plate tectonics has occurred on the present Earth. Subsequent to crustal accretion and prior to obduction, a broad array of processes leads to the modification of oceanic crust including tectonic overprint during ridge-to-trench seafloor spreading, chemical mass transfer and mineral modifications during low-temperature hydrothermal alteration and weathering, and biological activity. The nature of oceanic plates prior to subduction is key to describing and quantifying water and carbon fluxes into the deep Earth. The study of ophiolites, interpreted to represent obducted oceanic plate, has provided variable lines of information on the architecture of oceanic plates. However, the timing of mineralogical, chemical, physical, and biological processes during the aging of oceanic lithosphere exposed in ophiolites is often poorly constrained. Drilling is, therefore, still the only way to recover stratigraphically controlled samples of reasonable depth directly from the ocean floor.

Despite over 50 years of scientific ocean drilling, from the Deep Sea Drilling Project (DSDP, 1968-1983), the Ocean Drilling Program (ODP, 1985-2003), the Integrated Ocean Drilling Program (IODP, 2003-2013) to the International Ocean Discovery Program (IODP, 2013-present), only 18 holes have been drilled into more than $200 \mathrm{~m}$ of hard rocks of oceanic plates formed at the mid-ocean ridge (Michibayashi et al., 2019). Only one hole, Hole $1256 \mathrm{D}$, was successfully drilled into the intact uppermost gabbro after the penetration of basalts and sheeted dikes (Wilson et al., 2006; Fig. 1).

Chikyu is the first riser drilling-equipped scientific research vessel, which is capable of drilling deep enough to reach the mantle. An IODP mantle drilling proposal for the Pacific plate was submitted in 2012 (Umino et al., 2013). The Pacific Moho to Mantle drilling project, abbreviated as $\mathrm{M} 2 \mathrm{M}$, is aimed at obtaining the most pristine material so that it can serve as a reference for the less-altered oceanic plate. Because the mantle drilling will produce the deepest hole in the ocean floor, we can also address many other fundamental and diverse questions such as the nature of the Moho, the construction of the lower crust, and the limits of life. Thus, the M2M helps understand the life of the oceanic plate in novel and exciting ways.

Sites for the mantle drilling were selected by both scientific requirements and by technological constraints. First, the temperature of the Moho at the site must be below 250 and $150^{\circ} \mathrm{C}$ to safely drill and log, respectively. A location in a young hot plate is, therefore, not suitable for mantle drilling. Another major restriction is water depth, which should be shallower than circa $4000 \mathrm{~m}$ below sea level ( $\mathrm{mb}$ b.s.l. hereafter), because the anticipated maximum total length of the Chikyu riser system is $11000 \mathrm{~m}(4000 \mathrm{~m}$ water depth $+7000 \mathrm{~m}$ penetration to the Moho in normal oceanic crust). Therefore, most of the oceanic plate in the Pacific Ocean is too deep for mantle drilling.

Considering these constraints, three candidate drill sites have been suggested: off the coast of Hawaii (off-Hawaii hereafter), off the coast of Mexico (off-Mexico hereafter), and the Cocos plate (Umino et al., 2013; Fig. 2). The Cocos plate region, which includes ODP Site 1256, is advantageous as the shallowest water depth among the candidate regions, but this crust is higher than the temperature at which logging tools can be used properly. At the off-Mexico site, 20 to 30 Ma crust is likely low in temperature at the depth of the Moho, but there are no reasonable seismic data sets to evaluate the characteristics of the Moho. The Hawaiian North Arch region is a unique site of lithospheric flexure surrounding the Hawaiian Islands (Bianco et al., 2005) that elevates the seafloor to shallow enough depths for access by Chikyu. The water depth in the northeastern Hawaiian North Arch (Hawaiian North Arch region hereafter) is around $4200 \mathrm{~m}$ (Ohira et al., 2018): $\sim 1500 \mathrm{~m}$ shallower compared with the average depth of $5500 \mathrm{~m}$ for a normal $80 \mathrm{Ma}$ seafloor (McKenzie et al., 2005). Beyond the advantages and disadvantages of each site, we must obtain a clear seismic image of the Moho for the final site selection of the mantle drilling project. As shown below, a geophysical survey was conducted around the Hawaiian North Arch region, and new results on the diversity of the nature of the oceanic plate were reported (Ohira et al., 2018).

A workshop on developing a proposal for ocean drilling in the Hawaiian North Arch region was held in Kanazawa, Japan, on 6-7 November 2018. The goals of this workshop were (1) to share information about the Hawaiian North Arch region and other proposed hard-rock drilling sites that would use Chikyu, (2) to identify major scientific objectives for ocean drilling into the northeastern Hawaiian North Arch, and (3) to evaluate possible drilling sites; 37 researchers and students participated in this workshop.

\section{The Hawaiian North Arch region}

\subsection{Recent geophysical survey results}

In order to investigate the detailed seismic structure of the crust and the uppermost mantle at the off-Hawaii site, the Japan Agency for Marine-Earth Science and Technology (JAMSTEC) and the University of Hawai'i conducted a 2D marine seismic survey (an active-source refraction and reflection survey) in the central Pacific Ocean north of the Hawaiian Islands from August to November 2017 (Fig. 3). Multi-channel seismic (MCS) reflection data were acquired with a 444-channel, $6000 \mathrm{~m}$ long streamer cable with a $12.5 \mathrm{~m}$ interval between hydrophones, towed at a depth of $12 \mathrm{~m}$. For the acquisition of the wide-angle seismic data, five ocean bottom seismographs (OBSs) were deployed by the R/V Marcus G. Langseth and recovered by the R/V Kilo 


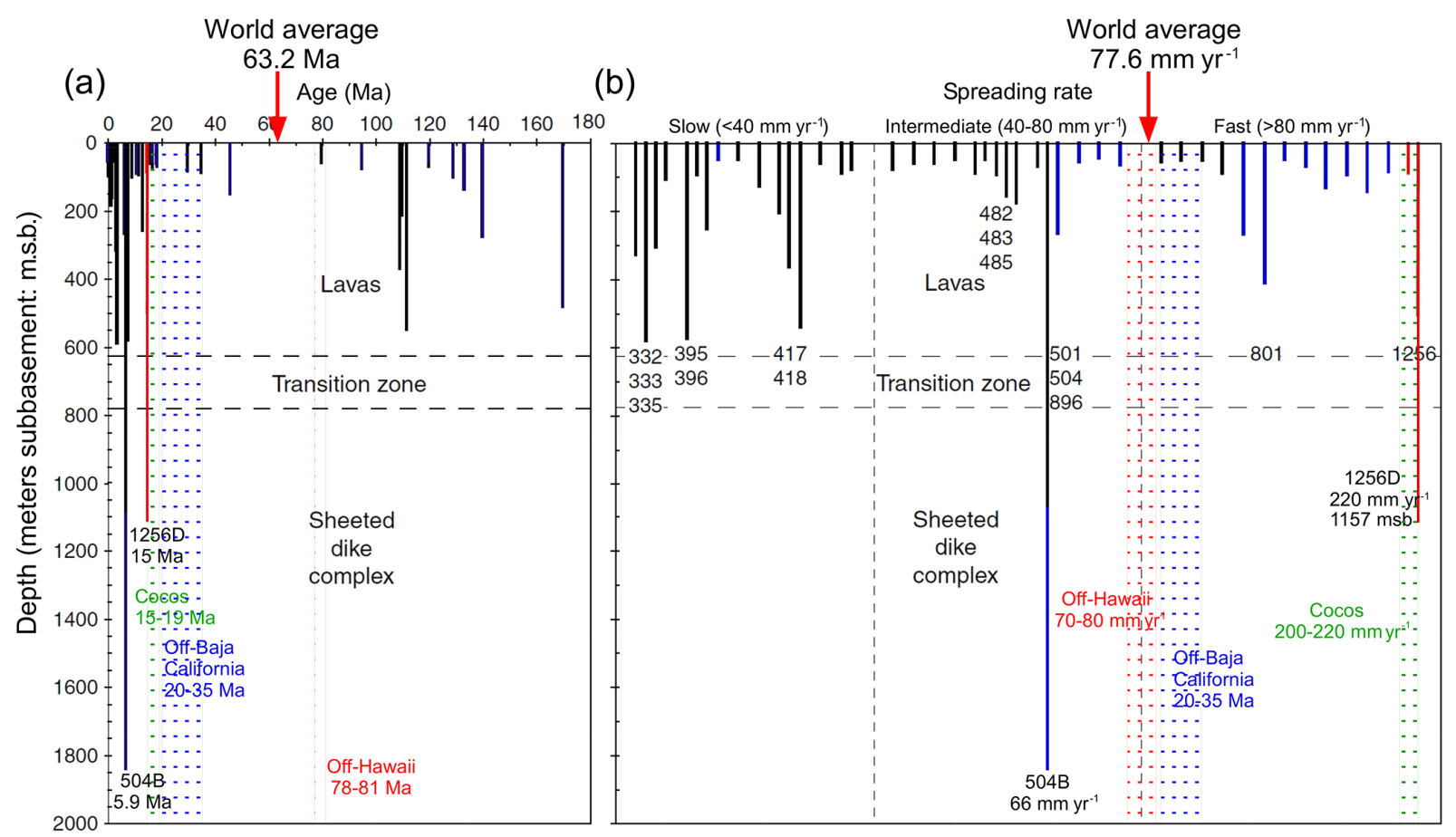

Figure 1. Ocean drill holes deeper than $50 \mathrm{~m}$ into the oceanic basement plotted against (a) the basement age and (b) categorized on the basis of spreading rate that formed the basement crust. World average age and spreading rate are based on the 3.6 min grid data from the Earth Byte age grid (Müller et al., 2008).

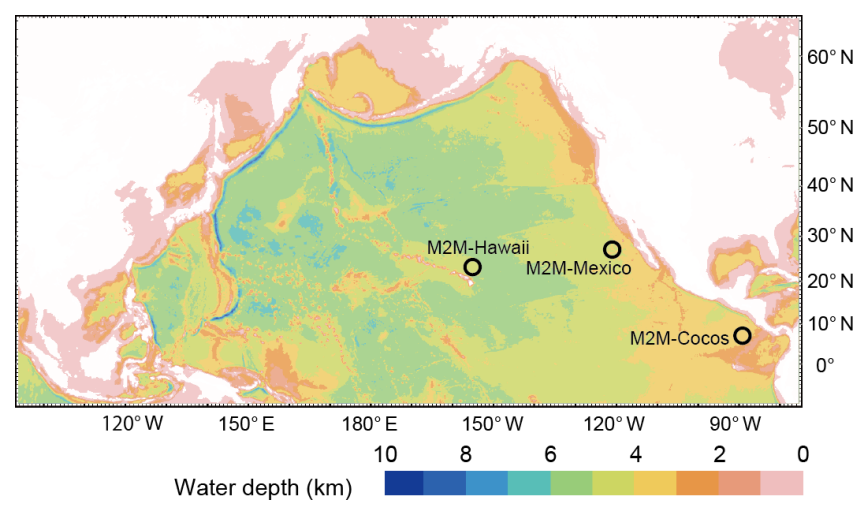

Figure 2. Bathymetric map of the Pacific Ocean showing candidate sites for the Moho to Mantle (M2M) drilling proposal.

Moana. Tuned airgun arrays (volume 7800 cubic inches) were fired by the R/V Kairei at intervals of $50 \mathrm{~m}$ along the EW, NS2, NS5 lines and at intervals of 50 and $200 \mathrm{~m}$ along the NS1 line. The total length of survey lines is $1150 \mathrm{~km}$.

The preliminary results of MCS profiles and P-wave velocity structure using OBSs were reported by Ohira et al. (2018). Their results show typical oceanic crustal structure of oceanic crust from the Hawaiian Arch to the ocean basin. The P-wave velocity structure in the uppermost mantle shows strong azimuthal anisotropy. To image the detailed reflection structure, we applied the prestack migration tech- nique using the initial velocity of the P-wave velocity structure by Ohira et al. (2018) for MCS data. The reflections from the Moho are characterized by images of a sharp, flat, continuous, and large amplitude (Fig. 4). The clear refraction phase from the boundary with an apparent velocity of more than $8 \mathrm{~km} \mathrm{~s}^{-1}$ is also observed in record sections of the OBSs (Ohira et al., 2018). Moho reflections from about every $2 \mathrm{~s}$ in two-way travel time below the basement are locally strong and continuous as expected for "normal" oceanic plate, whereas weak, diffuse, or no Moho reflections were observed in other parts of the seismic profile. The appearance of spatially variable Moho reflections is hereafter called Moho diversity. In order to recognize the spatial crustal characteristics for the drilling proposal, we focus on the 3-D image around the OBSs. Although the OBSs were sparsely arranged, many reflectors from the upper crust to the upper mantle are identified around the crossing point of survey lines (Figs. 5 and 6). It is important to obtain high-resolution velocity information in order to evaluate the Moho reflection for the drilling proposal.

\subsection{Significance of drilling into the Pacific crust on the Hawaiian North Arch}

Although seismic observations provide information of the architecture of the in situ oceanic crust, direct geological information of deeper portions of tectonically undisturbed normal oceanic crust can only be obtained by deep-ocean drilling. A 


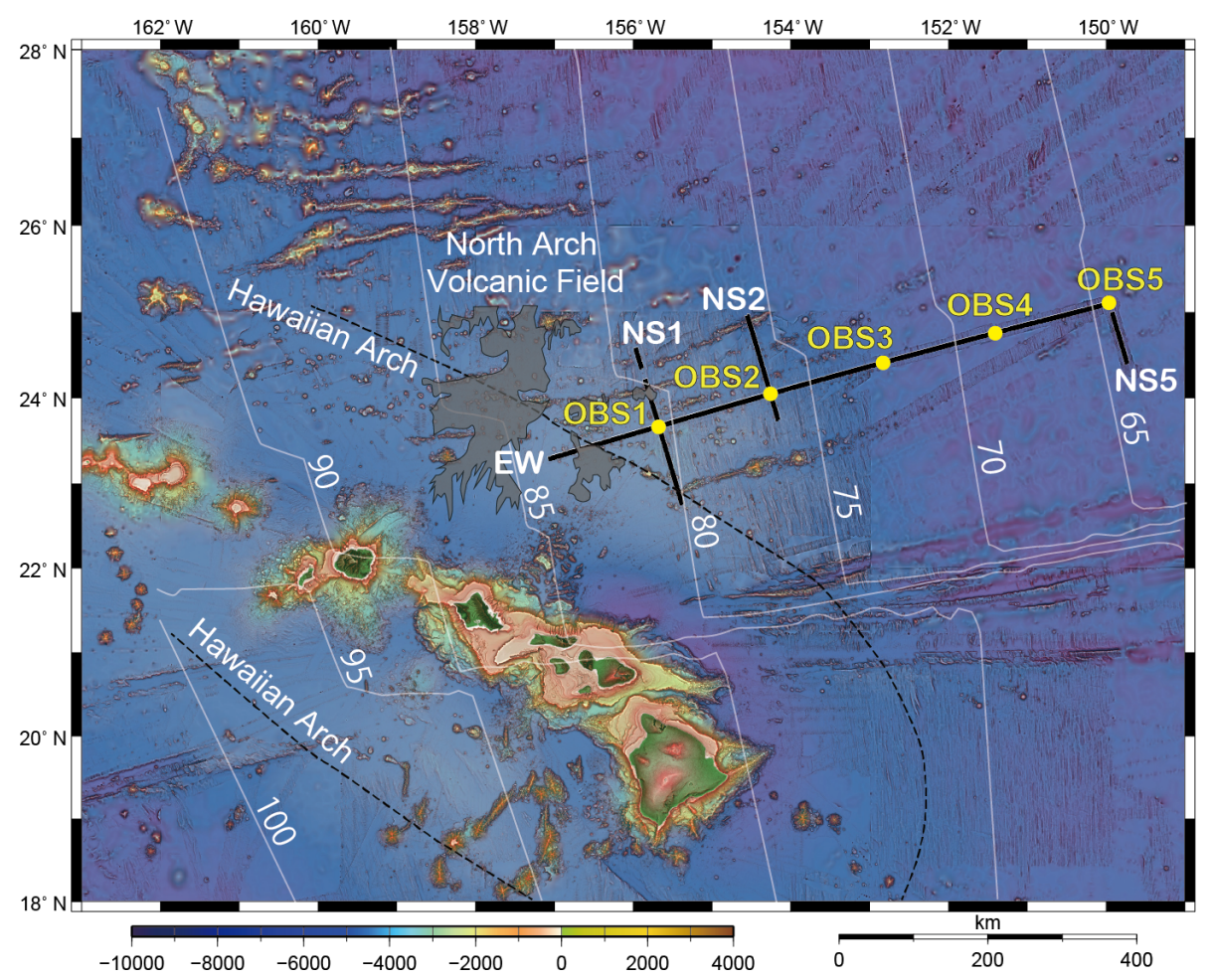

Figure 3. Map showing the seismic survey lines (black) northeast off the Hawaiian Islands. Yellow circles indicate the location of ocean bottom seismographs (OBSs). Thin white lines indicate seafloor age (Ma) from Müller et al. (2008). The black dashed line indicates the axis of the Hawaiian Arch (e.g., Ballmer et al., 2011; Holcomb and Robinson, 2004). The North Arch Volcanic Field, indicated by gray shading, is characterized by strong acoustic reflectivity (Clague et al., 1990, 2002; Normark et al., 1989).

(a)

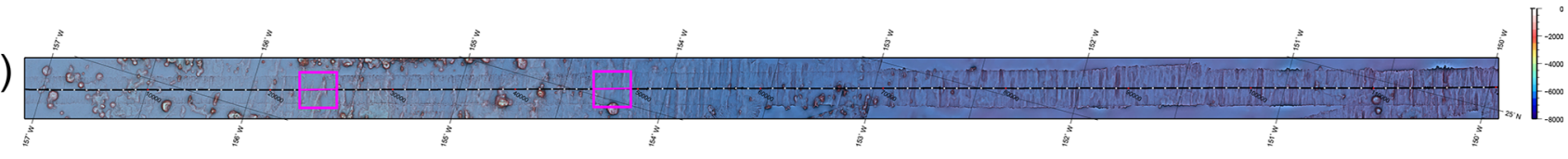

(b)

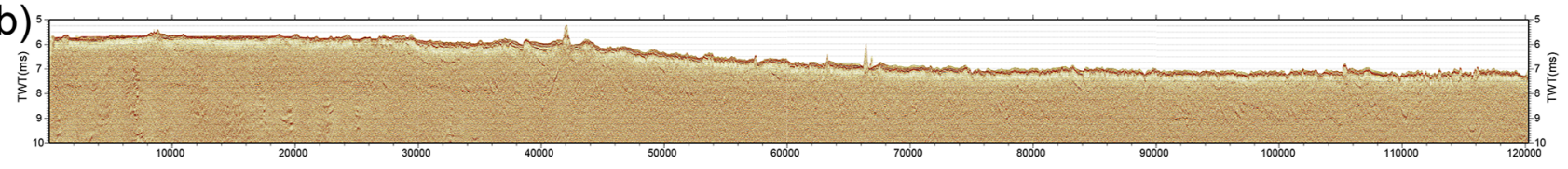

Figure 4. (a) Detailed bathymetry image along the EW line. Pink boxes show the location of Figs. 3 and 4. (b) Prestack time-migrated section of the EW line.

long-standing question is the nature of the seismic Layer 23 transition. Only Hole 504B penetrated through the Layer 2-3 transition within the sheeted dike complex, which appears to be controlled by alteration mineralogy or a change in porosity (Detrick et al., 1994; Alt et al., 1996). To test whether this Layer 2-3 transition is typical and true for crust spread at faster rates, Hole $1256 \mathrm{D}$ was aimed to drill into the $15 \mathrm{Ma}$ crust, created by spreading at $22 \mathrm{~cm} \mathrm{yr}^{-1}$. Although the hole ultimately reached the gabbro below the sheeted dikes, seismic data suggest the Layer 2-3 transition has not been reached yet (Teagle et al., 2006). Besides these two, only limited numbers of holes have been drilled more than a few hundred meters into the basement of normal oceanic crust (Fig. 1; Michibayashi et al., 2019).

Oceanic drillings deeper than $50 \mathrm{~m}$ into mid-oceanic basement were skewed to young $(<15 \mathrm{Ma})$ or slow-spread crust (Fig. 1), with a wide gap of crust age between 20 and $110 \mathrm{Ma}$, including the world average age of $62.5 \mathrm{Ma}$ and spreading rate of $7.6 \mathrm{~cm} \mathrm{yr}^{-1}$ (Fig. 1). For example, deep basement drillings (Holes 504B and 1256D) were conducted in young crust $(<15 \mathrm{Ma})$. Among the three candidate sites of $\mathrm{M} 2 \mathrm{M}$, only the off-Hawaii site can provide information about oceanic crust within the gap regarding age and spreading rate. Deep drilling at the off-Hawaii site, penetrating through the upper crust and into the gabbros, will enhance our un- 
(a)

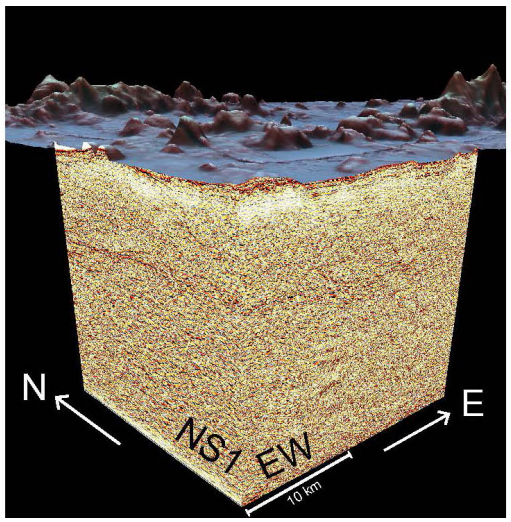

(b)

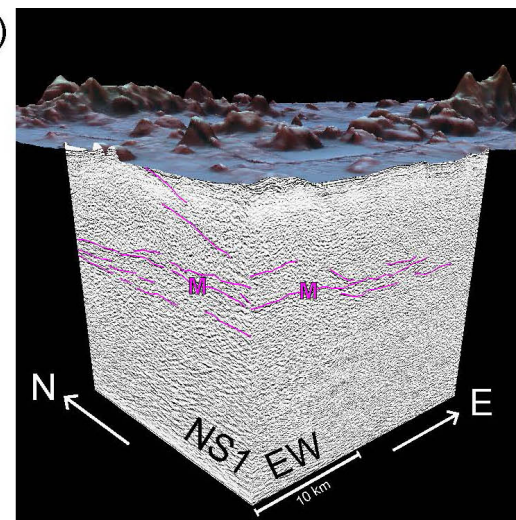

Figure 5. Three-dimensional view from the southwest to the northeast around the OBS1. (a) Prestack time-migrated section. (b) Reflector interpretation. M denotes the Moho reflection.

(a)

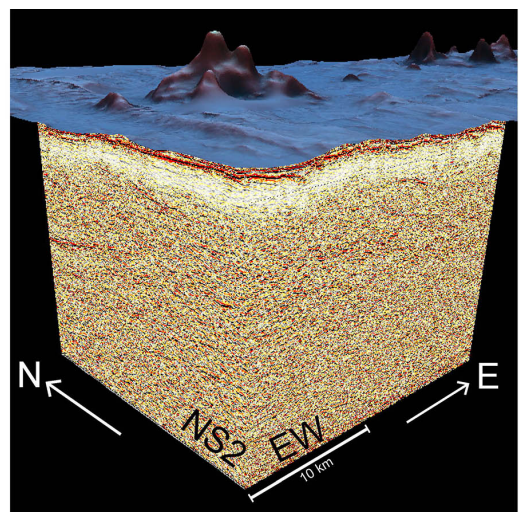

(b)

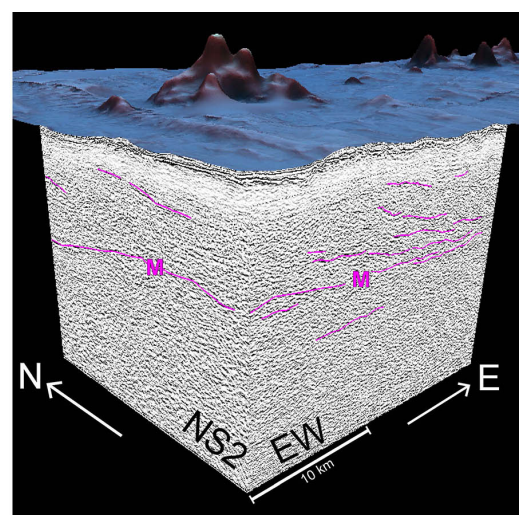

Figure 6. Three-dimensional view from the southwest to the northeast around the OBS2. (a) Prestack time-migrated section. (b) Reflector interpretation. M denotes the Moho reflection.

derstanding of the nature of the Layer 2-3 transition and the magmatic accretion and hydrothermal cooling at depth.

\subsection{North Arch volcanism and its effects on modifications of the oceanic plate}

The North Arch Volcanic Field covers $\sim 24000 \mathrm{~km}^{2}$ of ocean floor (Fig. 3). The volume and age of North Arch volcanism is poorly constrained, but they are estimated to be $10^{3} \mathrm{~km}^{3}$ and $0.5-1.5 \mathrm{Ma}$ (Clague et al., 2002). The calculated eruption rates are $\sim 1 \mathrm{~km}^{3} \mathrm{kyr}^{-1}$ corresponding with $\sim 1 \%-2 \%$ of the Kilauea eruption rate during peak times of eruption. The geochemistry of the lavas is highly alkaline basalts (Dixon and Clague, 2001). Due to the timing of eruptions, eruption rate, and chemistry, the North Arch volcanism is compared with the rejuvenated stage volcanic activity in the axial Hawaiian volcanic chain, which occurs after the shield until the post-shield stage (Garcia et al., 2010). Source mantle chemistry of the North Arch basalts is thought to connect them to the Hawaiian plume (Dixon and Clague, 2001; Garcia et al., 2010; Kimura et al., 2006). Estimated equilibrium melting pressure of the North Arch magmas corre- sponds with the lithosphere-asthenosphere boundary at 70$80 \mathrm{~km}$ (Li et al., 2004). Although the original seismic structure of the uppermost mantle is unaffected by the North Arch volcanism, crustal P-wave velocity $(\mathrm{Vp})$ beneath the North Arch, which is slower than for the undeformed Pacific plate by $0.2-0.3 \mathrm{~km} \mathrm{~s}^{-1}$, is ascribed to the presence of open cracks in the upper crust by extensional stress on the flexured North Arch lithosphere (Ohira et al., 2018).

\section{Workshop outcomes}

The unusually shallow seafloor allows Chikyu to access the lower oceanic crust and mantle in $80 \mathrm{Ma}$ seafloor. Drilling the off-Hawaii region is appealing based on two important geological features: (1) to date no lower crustal materials from the 80 Ma Pacific plate have been sampled (Fig. 1), and (2) unusual Moho diversity is observed in the Pacific plate (Figs. 4, 5, and 6). The workshop briefly summarized the previous hard-rock drilling results and considered what should be addressed by a new drilling project in the Hawaiian North Arch regions. The target depth of the drilling should exceed 
the seismic Layer 2 and Layer 3 boundary, in order to acquire a complete section of intact lower crust from the $80 \mathrm{Ma} \mathrm{Pa-}$ cific plate. In order to understand the nature of the oceanic plate, it is essential to observe and describe the conditions for the boundary and transition between seismic Layer 2 and Layer 3 by drilling. We also discussed the scientific objectives that can be achieved by drilling cores before reaching the target depth of the project.

\subsection{Lessons from previous drilling efforts}

\subsubsection{Formation of the oceanic crust}

Seismic observations along the Galapagos Spreading Center (GSC) show thickening on-axis and thinning total extrusive rocks with axial magma chamber (AMC) depth, indicating that axial valleys, which are formed by dike intrusions and/or fault displacement, develop to trap thick on-axis flows with a deepening AMC and a decreasing magma supply rate (Fig. 7; Blacic et al., 2004). For the GSC spreading rate of $4.5-5.5 \mathrm{~cm} \mathrm{yr}^{-1}$, more than $50 \%$ of flows in the axial valleys are pillows (Fig. 8; Ayadi et al., 1998; Bonatti and Harrison, 1988; Meyer and White, 2007; Tominaga et al., 2009; Tominaga and Umino, 2010; Susumu Umino, unpublished data, 2019). Consequently, the GSC is underlain by less dense pillows interbedded with fault breccias, which decreases the average density of the extrusive section with the development of an "apparent" level of neutral buoyancy (LNB; Rubin, 1990, 1995). The accumulated stress on the upper crust is relaxed by fault displacement in the uppermost extrusive rocks and by dike intrusions emplaced in the level of neutral buoyancy, which leads to the development of a rugged summit and axial troughs. This density structure of the upper crust is essentially the same as that of the ODP 504B crust (Dick et al., 1992; Fig. 9a).

In contrast, isostasy-dominated fast-spreading East Pacific Rise (EPR) extends solely by dike intrusions. Total extrusive thickness decreases with AMC depth, whereas on-axis flow thickness remains constant (Fig. 7; Hooft, 1996; Hooft et al., 1997). This indicates the absence of axial troughs even at a minimum magma budget, and the upper crust extends by dike intrusions without fault development. This is facilitated by the presence of dense extrusive rocks comprising more than $80 \%$ sheet flows, considering the spreading rates of $11-14 \mathrm{~cm} \mathrm{yr}^{-1}$ (Fig. 8). This crust architecture is primarily the same as that of the ODP 1256D crust. As is expected for the ultrafast spreading rate of $22 \mathrm{~cm} \mathrm{yr}^{-1}$ at Site $1256 \mathrm{D}$, the extrusive rocks are dominantly of massive and lobate sheet flows, which are as dense as the extruding magma (Teagle et al., 2006). This results in the upper crust being without an apparent LNB and the persistently over-pressurized axial magma chamber (Fig. 9b; Umino et al., 2008). Only a small increase in magmatic pressure or reduction in horizontal stress leads to dike intrusions followed by eruptions, and so the upper crust extends solely by dike intrusions.

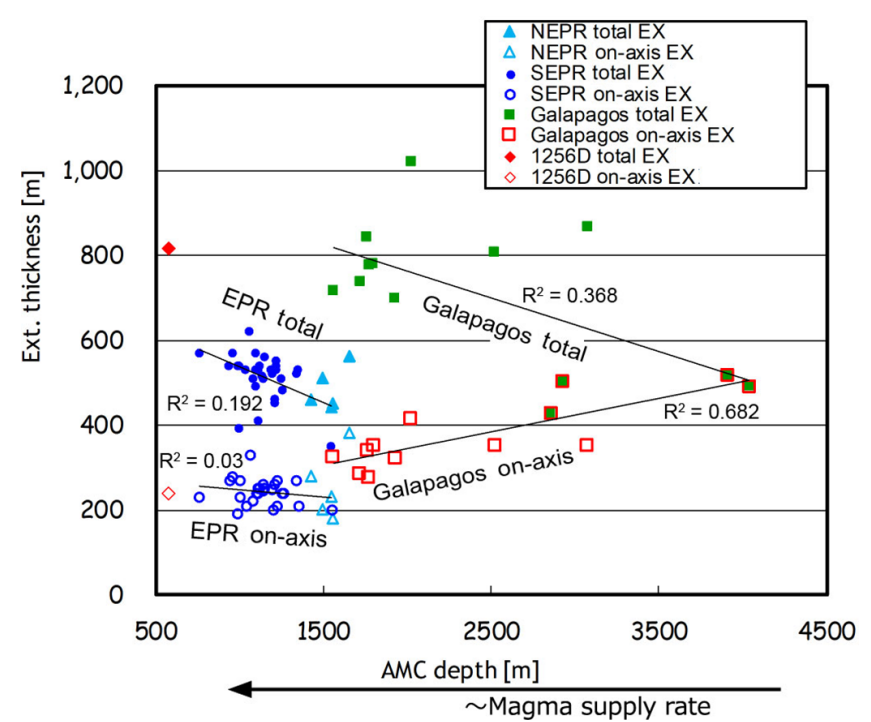

Figure 7. Extrusive thickness plotted against the AMC depth for the present Galapagos Spreading Center and the East Pacific Rise (EPR) segments and the $15 \mathrm{Ma} 1256 \mathrm{D}$ crust. Solid and open symbols are data based on total and on-axis extrusive thicknesses. Data sources are Hooft et al. (1997; SEPR, NEPR), Blacic et al. (2004; GSC), Tominaga et al. (2009; Hole 1256D), and Tominaga and Umino (2010; Hole 1256D).

These observations suggest that magma-starved upper crust will have less dense extrusive layers than magma underlain by a thicker-sheeted dike complex, whereas a magmatically robust upper crust has dense extrusive layers comparable to the magma underlain by a thin-sheeted dike complex. These two types of upper-crust architecture result from the interplay of magmatic accretion and tectonic deformation, which determines the bulk density of extrusive layers and axial topography. Spreading rate dependency of axial flow morphology and ridge topography suggests that high-density crust is formed on the ridge axis spreading at $>10 \mathrm{~cm} \mathrm{yr}^{-1}$ with sheet flows covering more than $70 \%$ of the smooth ridge axes, whereas low-density crust is formed on the ridge axis spreading at $<7 \mathrm{~cm} \mathrm{yr}^{-1}$ and is dominantly created by pillow flows with deeper axial troughs (Fig. 8). However, it is not clear whether the two types of upper-crust architecture gradually change from one type to the other or if there is any critical threshold that distinguishes two distinct types of upper crust. Upper crust created by spreading at an interval between 7 and $10 \mathrm{~cm} \mathrm{yr}^{-1}$ is, therefore, key to understanding the governing factors of the upper-crust architecture. The Hawaiian North Arch site on the 78-81 Ma Cretaceous crust with an estimated full spreading rate of $7-8 \mathrm{~cm} \mathrm{yr}^{-1}$ will provide a missing link that connects the two crust architectures and brings a more thorough understanding of seafloor spreading. 


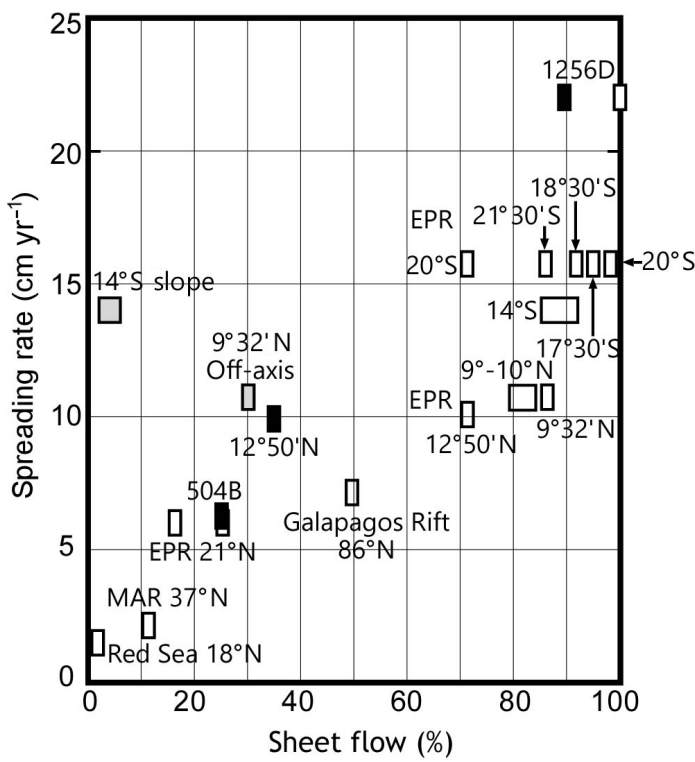

Figure 8. Spreading rate dependency of flow morphology of the mid-ocean ridges. Open, gray, and black symbols represent on-axis, ridge slope, and all data from on-axis to off-axis. Note that the spreading rate dependency of flow morphology stands only for onaxis flows. Even if the spreading rate exceeds $10 \mathrm{~cm} \mathrm{yr}^{-1}$, steep ridge slopes are overwhelmingly covered with elongate pillows. This is because flow morphology of basalt lava extruded at a low rate is mainly determined by the basement slopes and changes from lobate lobes $\left(\sim 0^{\circ}\right)$ through elongate, flattened pahoehoe-like lobes $\left(<7^{\circ}\right)$ to elongate pillows ( $>10^{\circ}$; Umino et al., 2000, 2002). The data sources are Ayadi et al. (1998), Bonatti and Harrison (1988), Meyer and White (2007), Tominaga et al. (2009), and Susumu Umino, unpublished data, 2019.

\subsubsection{Hydrothermal alteration of the oceanic crust}

Hydrothermal circulation is a pivotal process in the transfer of heat and mass in ridge crest and ridge flank environments and provides the nutrients and energy for (sub)seafloor life. Much of our knowledge about hydrothermal circulation is based on geophysical, mineralogical, chemical, and isotopic studies at or near spreading centers and ophiolites. In ophiolites, however, it is not always possible to differentiate between distinct hydrothermal events and processes prior to obduction. Except for two holes in the Pacific, 504B and 1256D, intact lower oceanic crust has not been sampled. The alteration patterns in both holes are broadly similar with low temperature phases in the volcanic section to (sub-)greenschist facies phases in the sheeted dikes (Teagle et al., 2006; Alt et al., 2010). The dike-gabbro transition, which was only sampled at $1256 \mathrm{D}$, shows multistage alteration patterns from early amphibolite facies alteration and granulite facies overprint to subsequent alteration at (subgreenschist facies conditions (Alt et al., 2010; Harris et al., 2017).
While Holes 504B and 1256D have provided a wealth of information about hydrothermal processes in relatively young oceanic crust, it is evident from heat flow measurements that fluid percolation continues to $65 \pm 10 \mathrm{Ma}$ (Stein and Stein, 1994). Heat transported by fluid flow in oceanic crust decreases with age, and it has been suggested that this is due to the clogging of pore space and decreased permeability (Stein and Stein, 1994). The volume of water circulating through ridge flanks and the aging oceanic crust (1$65 \mathrm{Ma}$ ) may be as high as $2 \times 10^{16} \mathrm{~kg} \mathrm{yr}^{-1}$, which is orders of magnitude higher than water circulation through ridge crest hydrothermal systems (e.g., Schultz and Elderfield, 1997). Beyond $65 \mathrm{Ma}$ predicted and measured heat flow converge, but fluid-rock interaction may still continue. As a result, the oceanic basement rock may undergo prolonged oxidation (e.g., Klein et al., 2017), mineral dissolution, and precipitation, as well as chemical and isotopic changes, though it is largely isolated from the water column by sediments. While the dissolution and precipitation of minerals control porosity with important consequences for fluid flow, heat and mass transfer, and life (see below), we have been unable to assess these processes in aged intact oceanic crust due the lack of samples specifically from below the volcanic section.

\subsection{Moho diversity in the Pacific plate}

Aging of lithosphere is the cause of the diversity of the Moho in the Pacific plate (Ohira et al., 2018). The Moho reflection is weak in magma-starved segments and becomes obscured by deep crustal intrusions and by hydration and deformation of the lithosphere. Correlation of magma geochemistry, alteration, stress conditions, and seismic structures investigated by drilling enables us to understand the relationship between the Moho diversity and the aging of oceanic lithosphere, as well as by comparing these results with data for younger crust at Sites 504 and 1256 and older crust at Site 801.

P-wave velocity in the uppermost mantle obtained from the forward analyses in the seismic lines of Fig. 3 is 8.50 8.65 and 7.9-8.0 $\mathrm{km} \mathrm{s}^{-1}$ across and along the paleo-ridge direction, respectively (Fig. 9 of Ohira et al., 2018), which is common for the lithospheric upper mantle produced at fastspreading ridges. This suggests that the uppermost mantle preserves its original structure formed at the ridge. The seismic cross section shows a reduction of crustal P-wave velocity from the un-deformed Pacific plate of $\sim 7.0 \mathrm{~km} \mathrm{~s}^{-1}$ to the deformed North Arch with a Vp of $\sim 6.7 \mathrm{~km} \mathrm{~s}^{-1}$ (Fig. 9 of Ohira et al., 2018). However, shallow faults found in the Layer 1 sediment do not differ much between the two areas. Further, the intra-crustal and Moho reflectors are considerably heterogeneous over these areas, and differences between the two areas are obscure (Ohira et al., 2018).

The North Arch magmatism also potentially modified the original architecture of the Pacific plate. The temperature of an $80 \mathrm{Ma}$ oceanic crust is low $\left(100-200^{\circ} \mathrm{C}\right.$; McKenzie et 
(a)

Lithostatic (magmastatic) + Hydrostatic pressure $[\mathrm{MPa}]$
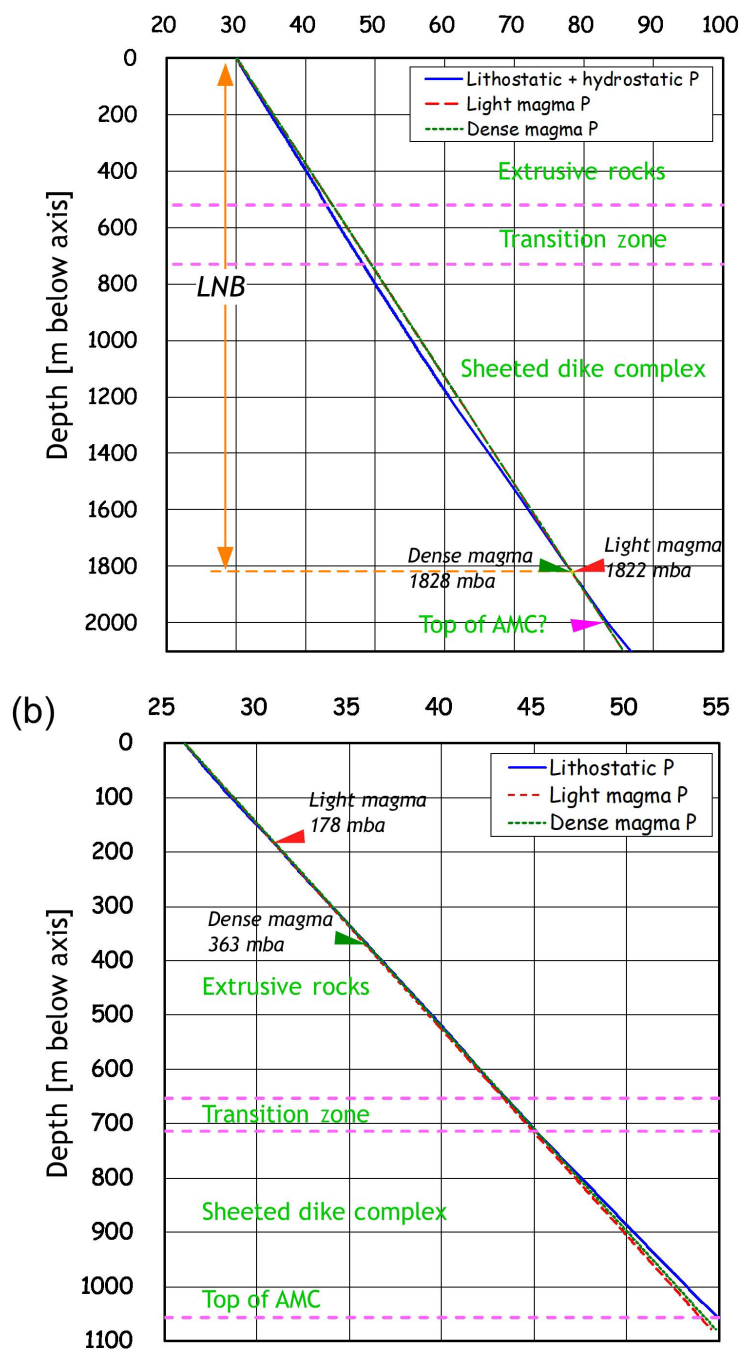

Figure 9. Estimated lithostatic-magmastatic pressure variations for Sites (a) 504B and (b) 1256D when they were at the ridge axis. (a) Using the lithodensity logs obtained during Leg 111, density structures of the upper crust were estimated by integrating all density data $>2000 \mathrm{~kg} \mathrm{~m}^{-3}$ with depth, assuming water depth at the ridge axis of $3000 \mathrm{~m}$, identical to that of the present Costa Rica Rift. The uppermost $50 \mathrm{~m}$ thick flows were emplaced out of the neovolcanic zone (Ayadi et al., 1998), and so they were eliminated from the lithostatic pressure estimate. Hole 504B lavas and dikes are nearly aphyric, relatively primitive $(\mathrm{Mg} \#(100 \times \mathrm{Mg} /[\mathrm{Mg}+\mathrm{Fe}]) 68 \%-56 \%, \mathrm{MgO} 8 \%-$ $9.5 \%, \mathrm{FeO}^{*}$ (total $\mathrm{Fe}$ as $\mathrm{FeO}$ ) $8 \%-10.5 \%$ ), and are among the most depleted end-members of NMORB (Dick et al., 1992; Umino, 2003). Magma density was estimated using the program adiabat_1ph (Smith and Asimow, 2005) run in MELTS (Ghiorso and Sack, 1995) mode for representative primitive and differentiated compositions at an appropriate AMC depth up to the surface and at liquidus temperatures. The lower crust gabbro is presumed to be close to the bottom of the hole at $1526 \mathrm{~m}$ below seafloor; however, it is yet to be reached. Consequently, the AMC beneath the ridge axis is assumed to be at $1060 \mathrm{~m}$ in depth. Oxygen fugacity was assumed to be 2 log 10 units below the quartzfayalite-magnetite buffer (Christie et al., 1986). (b) Hole 1256D was penetrated through a $15 \mathrm{Ma}$ ultrafast-spread $\left(22 \mathrm{~cm} \mathrm{yr}^{-1}\right) \mathrm{crust} \mathrm{formed}^{-1}$ at the East Pacific Rise. Assuming the water depth at ridge axis of $2600 \mathrm{~m}$, the densities of magmas at the AMC pressures of $53.7 \mathrm{MPa}$ are estimated as 2698 and $2703 \mathrm{~kg} \mathrm{~m}^{-3}$ for primitive $\left(\mathrm{FeO}^{*} 8.39 \%\right)$ and differentiated (FeO* $10.2 \mathrm{wt} \%$ ) magmas, respectively. Please refer to Umino et al. (2008) for more detail.

al., 2005). Therefore, the magma chambers that developed in such cold oceanic crust are unlikely to be long-lived tholeiitic shallow systems like Kilauea (Poland et al., 2014), but rather, they are likely deep-seated chambers near the lithosphereasthenosphere boundary, as estimated by the post-shield al- kali basalts (Kimura et al., 2006). Basalt feeder dikes are likely present within the Layer 3 gabbro. Such alkali basalt dikes appear to provide little thermal and chemical overprints of the surrounding crust. All those assumptions can be tested by drilling because of the contrasting compositions of the 
$\sim 80$ Myr old mid-ocean ridge-type Pacific plate basalts and the $\sim 0.5-1.5 \mathrm{Myr}$ old alkaline North Arch basalts.

\subsection{Deep biosphere in relatively old oceanic crust}

The relatively old oceanic plate results in temperatures of $<150^{\circ} \mathrm{C}$ even at the Moho depths, which is close to the upper temperature limit of life. Thus, the potential drilling sites are intriguing targets for studying a deep subseafloor biosphere in aged, hydrothermally overprinted igneous rocks of the lower crust.

In contrast to sedimentary rocks, crystalline igneous rocks are generally low in organic carbon and porosity, thus providing extremely low nutrient and energy supplies. However, microorganisms are possibly transported and migrate to fractures and interconnected pores. Compared to sedimentary rocks, the habitability of igneous rocks and their altered equivalents in the lower oceanic crust remain poorly understood and limited to slow-spreading ridges (Mason et al., 2010). Exploration of the deep subseafloor biosphere from the lower crust of intermediate-to-fast-spreading oceanic plates will provide a unique opportunity to investigate the diversity and survival strategies of microbial ecosystems in rocks that make up the majority of the Pacific seafloor.

\subsection{Nature of the North Arch volcano}

No primitive basalt was found from the North Arch area, suggesting either primitive basalts are undiscovered beneath sedimentary cover or efficiently differentiated (Dixon and Clague, 2001; Garcia et al., 2010). The presence of cracks in the upper crust on the flexured North Arch lithosphere reduces the bulk density of the upper crust, leading to the presence of apparent LNB in the mid-crust, where magma is trapped, fractionates crystals, and interacts with the wall rocks. Fundamental issues are if there is any primitive basalt hidden beneath differentiated lavas on the surface, how any mid-crustal magma chambers formed associated with the flexure, and to what extent and how the lithosphere is geochemically altered and structurally disturbed by the North Arch volcanism. Assimilation of Layer 2-3 (basalt-gabbro) characteristics by the North Arch basalts can also be explored by geochemical signatures, such as lower $\mathrm{O}, \mathrm{Sr}$, and $\mathrm{Pb}$ isotopes. Those can also be tested by drilling to recover more primitive North Arch basalt samples.

\subsection{Giant Hawaiian landslides: frequency, size, and mechanics}

The enormous size (up to $8.5 \mathrm{~km}$ of relief and $80000 \mathrm{~km}^{3}$ ) and rapid growth $(\sim 1$ to $1.5 \mathrm{Myr})$ of Hawaiian volcanoes causes them to become gravitationally unstable and collapse (Moore et al., 1989). These collapses have generated some of the largest landslides on Earth, and they have undoubtedly produced colossal tsunami (e.g., Satake et al., 2002). Dozens of giant landslides, some with deposits extending more than $200 \mathrm{~km}$ from their source and with volumes $>1000 \mathrm{~km}^{3}$, have been recognized along the Hawaiian Ridge (Moore et al., 1994). Considering only the deposits exposed on the ocean floor, the Hawaiian Ridge has major landslides every $32 \mathrm{~km}$ along its length. This suggests that a major landslide has occurred about every $350 \mathrm{kyr}$ (Moore et al., 1994). However, drilling at ODP Site 1223 revealed that Ko'olau Volcano, a moderately sized Hawaiian volcano, produced at least four major and three other slides during a period of $\sim 0.7 \mathrm{Myr}$, and many more potential landslide deposits appear to be buried at depth (Garcia et al., 2006). Thus, existing data argue that large landslides are a common occurrence (once in $\sim 100 \mathrm{kyr}$ ) and are an important geologic hazard that requires additional investigation to assess their impact on the circum-Pacific regions. Drilling at the proposed site north of the main Hawaiian Islands will allow the frequency, size, and possible failure mechanics of such landslides to be better understood.

\section{Summary}

The diversity of the nature of the oceanic plate was reported by a geophysical survey around the Hawaiian North Arch region, which is one of three candidate drill sites of the Pacific Moho to Mantle drilling project. We summarize the scientific rationale of a workshop on developing a proposal for ocean drilling in the Hawaiian Arch region located in 78$81 \mathrm{Ma}$ Cretaceous crust with an estimated full spreading rate of $7-8 \mathrm{~cm} \mathrm{yr}^{-1}$. The main objective of the drilling proposal is to understand the architecture and evolution of the oceanic crust and the relationship between the diversity of the Moho and aging of oceanic lithosphere. Previous drilling into tectonically undisturbed oceanic crust was limited and skewed to young $(<15 \mathrm{Ma})$ and slow $\left(<4 \mathrm{~cm} \mathrm{yr}^{-1}\right)$ spreading rates. This leaves a substantial gap in our knowledge about crust age between 20 and $110 \mathrm{Ma}$, including the world average age of $63 \mathrm{Ma}$ and spreading rate of $8 \mathrm{~cm} \mathrm{yr}^{-1}$. The Hawaiian North Arch site, with a spreading rate of $7-10 \mathrm{~cm} \mathrm{yr}^{-1}$, will enhance our understanding of the transition between slowspreading ridges, which are dominated by extension, and fast-spreading ridges, which dominated by magmatism. The drilling into the Hawaiian North Arch region can also address other scientific objectives such as investigating a deep biosphere in relatively old oceanic crust, the North Arch magmatism, and giant Hawaiian landslides.

\section{Participants of the hard-rock drilling workshop in Kanazawa, Japan}

Natsue Abe (JAMSTEC), Yuya Akamatsu (Hiroshima Univ.), Norikatsu Akizawa (Univ. Tokyo), Bidisha Dey (Hiroshima Univ.), Henry Dick (WHOI), Mike Garcia (Univ. Hawaii), Juan Miguel Guotana (Kanazawa Univ.), Mori- 
hisa Hamada (JAMSTEC), Takeshi Hanyu (JAMSTEC), Defry Hastria (Kanazawa Univ.), Kohei Hatakeyama (Hiroshima Univ.), Yasuhiro Hirai (Kanazawa Univ.), Takehiro Hirayama (Hiroshima Univ.), Benoit Ildefonse (Montpellier Univ.), Yuki Kakihata (Shizuoka Univ.), Ikuo Katayama (Hiroshima Univ.), Jun-Ichi Kimura (JAMSTEC), Frieder Klein (WHOI), Shuichi Kodaira (JAMSTEC), Jürgen Koepke (Hanover Univ.), Katsuyoshi Michibayashi (Nagoya Univ.), Tomoyuki Mizukami (Kanazawa Univ.), Tomoaki Morishita (Kanazawa Univ.), Yasuhiro Nanba (JAMSTEC), Khac Du Nguyen (Kanazawa Univ.), Yohei Ogusu (Kanazawa Univ.), Yasuhiko Ohara (Japan Coast Guard/JAMSTEC), Shigeaki Ono (JAMSTEC), Kenji Shimizu (JAMSTEC), Gen Shimoda (AIST), Eiichi Takazawa (Niigata Univ.), Akihiro Tamura (Kanazawa Univ.), Yoshihiko Tamura (JAMSTEC), Christian Timm (GEOMAR), Masako Tominaga (WHOI), Susumu Umino (Kanazawa Univ.), and Mikiya Yamashita (JAMSTEC).

Data availability. No data sets were used in this article.

Author contributions. TM, SU, SO, and KM organized this workshop in Kanazawa, Japan. SU and JK contributed North Arch volcanism data, MY contributed geophysical site survey data, MT interpreted the logging data, FK contributed data regarding hydrothermal alteration of the oceanic crust and the deep biosphere, and MG contributed data regarding North Arch volcanism and giant Hawaiian landslides. TM took the lead in writing the initial draft of the manuscript. All authors contributed improvements to the final paper.

Competing interests. The authors declare that they have no conflict of interest.

Acknowledgements. We are grateful to Akihiro Tamura and Hiromi Tsuji for their support during the workshop. This workshop was financially supported by the J-DESC, the Japan Geoscience Union, and the Kanazawa University SAKIGAKE project. Comments from Kevin Johnson, Jeffrey Alt, and the journal editor significantly improved the manuscript. This study was partly supported by the Grants-in-Aid for Scientific Research Program of the Ministry of Education, Culture, Sports, Science and Technology of Japan awarded to Tomoaki Morishita (grant no. 19H01990). This is SOEST no. 10787.

Financial support. This workshop has been supported by JDESC, the Japan Geoscience Union, and Kanazawa University SAKIGAKE project, and the Grants-in-Aid for Scientific Research program of the Ministry of Education, Culture, Sports, Science and Technology of Japan (grant no. 19H01990: TM).
Review statement. This paper was edited by Will Sager and reviewed by Kevin Johnson and Jeffrey Alt.

\section{References}

Alt, J. C., Laverne, C., Vanko, D. A., Tartarotti, P., Teagle, D. A. H., Bach, W., Zuleger, E., Erzinger, J., Honnorez, J., Pezard, P. A., Becker, K., Salisbury, M. H., and Wilkens, R. H.: Hydrothermal alteration of a section of upper oceanic crust in the Eastern Equatorial Pacific: A synthesis of results from site 504 (DSDP Legs 69, 70, and 83, and ODP Legs 111, 137, 140, and 148), in: Proc. ODP, Sci. Results, edited by: Alt, J. C., Kinoshita, H., Stokking, L. B., and Michael, P. J., 148, 417-434, Ocean Drilling Program, College Station, TX, USA, 1996.

Alt, J. C., Laverne, C., Coggon, R. M., Teagle, D. A. H., Banerjee, N. R., Morgan, S., Smith-Duque, C. E., Harris, M., and Galli, L.: Subsurface structure of a submarine hydrothermal system in ocean crust formed at the East Pacific Rise, ODP/IODP Site 1256, Geochem. Geophy. Geosy., 11, https://doi.org/10.1029/2010GC003144, 2010.

Ayadi, M., Pezard, P. A., Laverne, C., and Bronner, G.: Multi-scalar structure at DSDP/ODP Site 504, Costa Rica Rift, I: stratigraphy of eruptive products and accretion processes, Geol. Soc. London, Spec. Publ., 136, 297-310, https://doi.org/10.1144/GSL.SP.1998.136.01.25, 1998.

Ballmer, M. D., Ito, G., Van Hunen, J., and Tackley, P. J.: Spatial and temporal variability in Hawaiian hotspot volcanism induced by small-scale convection, Nat. Geosci., 4, 457-460, https://doi.org/10.1038/ngeo1187, 2011.

Bianco, T. A., Ito, G., Becker, J. M., and Garcia, M. O.: Secondary Hawaiian volcanism formed by flexural arch decompression, Geochem. Geophy. Geosy., 6, https://doi.org/10.1029/2005GC000945, 2005.

Blacic, T. M., Ito, G., Canales, J. P., Detrick, R. S., and Sinton, J.: Constructing the crust along the Galapagos Spreading Center $91.3^{\circ}-95.5^{\circ} \mathrm{W}$ : Correlation of seismic layer $2 \mathrm{~A}$ with axial magma lens and topographic characteristics, J. Geophys. Res.Sol. Ea., 109, https://doi.org/10.1029/2004JB003066, 2004.

Bonatti, E. and Harrison, C. G. A.: Eruption styles of basalt in oceanic spreading ridges and seamounts: Effect of magma temperature and viscosity, J. Geophys. Res., 93, 2967, https://doi.org/10.1029/JB093iB04p02967, 1988.

Christie, D. M., Carmichael, I. S. E., and Langmuir, C. H.: Oxidation states of mid-ocean ridge basalt glasses, Earth Planet. Sc. Lett., 79, 397-411, https://doi.org/10.1016/0012821X(86)90195-0, 1986.

Clague, D. A., Holcomb, R. T., Sinton, J. M., Detrick, R. S., and Torresan, M. E.: Pliocene and Pleistocene alkalic flood basalts on the seafloor north of the Hawaiian islands, Earth Planet. Sc. Lett., 98, 175-191, https://doi.org/10.1016/0012821X(90)90058-6, 1990.

Clague, D. A., Uto, K., Satake, K., and Davis, A. S.: Eruption style and flow emplacement in the Submarine North Arch Volcanic Field, Hawaii, in: Hawaiian Volcanoes: Deep Underwater Perspectives, edited by: Takahashi, E., Lipman, P. W., Garcia, M. O., Naka, J., and Aramaki, S., Geophys. Monograph, 128, 6584, https://doi.org/10.1029/GM128p0065, 2002. 
Detrick, R., Collins, J., Stephen, R., and Swift, S.: In situ evidence for the nature of the seismic layer $2 / 3$ boundary in oceanic crust, Nature, 370, 288-290, https://doi.org/10.1038/370288a0, 1994.

Dick, H. J. B., Erzinger, J., and Stokking, L. B.: Proceedings of the Ocean Drilling Program, 140 Initial Reports, edited by: Dick, H. J. B., Erzinger, J., and Stokking, L. B., Ocean Drilling Program, Texas, 1992.

Dixon, J. E. and Clague, D. A.: Volatiles in Basaltic Glasses from Loihi Seamount, Hawaii: Evidence for a Relatively Dry Plume Component, J. Petrol., 42, 627-654, https://doi.org/10.1093/petrology/42.3.627, 2001.

Garcia, M. O., Sherman, S. B., Moore, G. F., Goll, R., Popova-Goll, I., Natland, J. H., and Acton, G.: Frequent landslides from Koolau Volcano: Results from ODP Hole 1223A, J. Volcanol. Geoth. Res., 151, 251-268, https://doi.org/10.1016/j.jvolgeores.2005.07.035, 2006.

Garcia, M. O., Swinnard, L., Weis, D., Greene, A. R., Tagami, T., Sano, H., and Gandy, C. E.: Petrology, Geochemistry and Geochronology of Kaua'i Lavas over 4.5 Myr: Implications for the Origin of Rejuvenated Volcanism and the Evolution of the Hawaiian Plume, J. Petrol., 51, 1507-1540, https://doi.org/10.1093/petrology/egq027, 2010.

Ghiorso, M. S. and Sack, R. O.: Chemical mass transfer in magmatic processes IV. A revised and internally consistent thermodynamic model for the interpolation and extrapolation of liquid-solid equilibria in magmatic systems at elevated temperatures and pressures, Contrib. Mineral. Petr., 119, 197-212, https://doi.org/10.1007/BF00307281, 1995.

Harris, M., Coggon, R. M., Wood, M., Smith-Duque, C. E., Henstock, T. J., and Teagle, D. A. H.: Hydrothermal cooling of the ocean crust: Insights from ODP Hole 1256D, Earth Planet. Sci. Lett., 462, 110-121, https://doi.org/10.1016/j.epsl.2017.01.010, 2017.

Holcomb, R. T. and Robinson, J. E.: Maps of Hawaiian Islands exclusive economic zone interpreted from GLORIA sidescan-sonar imagery, Sci. Investig. Map 2824, https://doi.org/10.3133/sim2824, 2004.

Hooft, E.: Constraining crustal emplacement processes from the variation in seismic layer $2 \mathrm{~A}$ thickness at the East Pacific Rise, Earth Planet. Sc. Lett., 142, 289-309, https://doi.org/10.1016/0012-821X(96)00101-X, 1996.

Hooft, E. E. E., Detrick, R. S., and Kent, G. M.: Seismic structure and indicators of magma budget along the Southern East Pacific Rise, J. Geophys. Res.-Sol. Ea., 102, 27319-27340, https://doi.org/10.1029/97JB02349, 1997.

Kimura, J.-I., Sisson, T. W., Nakano, N., Coombs, M. L., and Lipman, P. W.: Isotope geochemistry of early Kilauea magmas from the submarine Hilina bench: The nature of the Hilina mantle component, J. Volcanol. Geoth. Res., 151, 51-72, https://doi.org/10.1016/j.jvolgeores.2005.07.024, 2006.

Klein, F., Marschall, H. R., Bowring, S. A., Humphris, S. E., and Horning, G.: Mid-ocean Ridge Serpentinite in the Puerto Rico Trench: from Seafloor Spreading to Subduction, J. Petrol., 58, 1729-1754, https://doi.org/10.1093/petrology/egx071, 2017.

Li, X., Kind, R., Yuan, X., Wölbern, I., and Hanka, W.: Rejuvenation of the lithosphere by the Hawaiian plume, Nature, 427, 827-829, https://doi.org/10.1038/nature02349, 2004.

Mason, O. U., Nakagawa, T., Rosner, M., Van Nostrand, J. D., Zhou, J., Maruyama, A., Fisk, M. R., and Giovan- noni, S. J.: First Investigation of the Microbiology of the Deepest Layer of Ocean Crust, PLoS ONE 5, e15399, https://doi.org/10.1371/journal.pone.0015399, 2010.

McKenzie, D., Jackson, J., and Priestley, K.: Thermal structure of oceanic and continental lithosphere, Earth Planet. Sc. Lett., 233, 337-349, https://doi.org/10.1016/j.eps1.2005.02.005, 2005.

Meyer, J. D. and White, S. M.: Lava morphology mapping by expert system classification of high-resolution side-scan sonar imagery from the East Pacific Rise, $9^{\circ}-10^{\circ} \mathrm{N}$, Mar. Geophys. Res., 28, 81-93, https://doi.org/10.1007/s11001-007-9015-8, 2007.

Michibayashi, K., Tominaga, M., Ildefonse, B., and Teagle, D.: What Lies Beneath: The Formation and Evolution of Oceanic Lithosphere, Oceanography, 32, 138-149, https://doi.org/10.5670/oceanog.2019.136, 2019.

Moore, J. G., Clague, D. A., Holcomb, R. T., Lipman, P. W., Normark, W. R., and Torresan, M. E.: Prodigious submarine landslides on the Hawaiian Ridge, J. Geophys. Res., 94, 17465, https://doi.org/10.1029/JB094iB12p17465, 1989.

Moore, J. G., Normark, W. R., and Holcomb, R. T.: Giant Hawaiian Landslides, Annu. Rev. Earth Pl. Sc., 22, 119-144, https://doi.org/10.1146/annurev.ea.22.050194.001003, 1994.

Müller, R. D., Sdrolias, M., Gaina, C., and Roest, W. R.: Age, spreading rates, and spreading asymmetry of the world's ocean crust, Geochem. Geophy. Geosy., 9, https://doi.org/10.1029/2007GC001743, 2008.

Normark, W. R., Holcomb, R. T., Searle, R. C., Somers, M. L., and Gutmacher, C. E.: Cruise report; Hawaiian GLORIA legs 3 and 4, F3-88-HW and F4-88-HW, Dept. of the Interior, U.S. Geological Survey, 1989.

Ohira, A., Kodaira, S., Moore, G. F., Yamashita, M., Fujiwara, T., Kaiho, Y., Miura, S., and Fujie, G.: Active-source seismic survey on the northeastern Hawaiian Arch: insights into crustal structure and mantle reflectors, Earth Planets Space, 70, 121, https://doi.org/10.1186/s40623-018-0891-8, 2018.

Poland, M. P., Miklius, A., and Montgomery-Brown, E. K.: Magma Supply, Storage, and Transport at Shield-Stage Hawaiian Volcanoes, chap. 5, in: Characteristics of Hawaiian Volcanoes, edited by: Poland, M. P., Takahashi, T. J., and Landowski, C. J., U.S. Geological Survey Professional Paper, U.S. Geological Survey, Reston, VA, 179-234, 2014.

Rubin, A. M.: A comparison of rift-zone tectonics in Iceland and Hawaii, B. Volcanol., 52, 302-319, https://doi.org/10.1007/BF00304101, 1990.

Rubin, A. M.: Propagation of Magma-Filled Cracks, Annu. Rev. Earth Pl. Sc., 23, 287-336, https://doi.org/10.1146/annurev.ea.23.050195.001443, 1995.

Satake, K., Smith, J. R., and Shinozaki, K.: Three-dimensional reconstruction and tsunami model of the Nuuanu and Wailau giant landslides, Hawaii, Geophys. Monogr. Ser., 128, 333-346, https://doi.org/10.1029/GM128p0333, 2002.

Schultz, A. and Elderfield, H.: Controls on the physics and chemistry of seafloor hydrothermal circulation, edited by J. R. Cann, H. Elderfield, and A. Laughton, Philos. T. R. Soc. A, 355, 387425, https://doi.org/10.1098/rsta.1997.0014, 1997.

Smith, P. M. and Asimow, P. D.: Adiabat_1ph: A new public frontend to the MELTS, pMELTS, and pHMELTS models, Geochem. Geophy. Geosy., 6, 1-8, https://doi.org/10.1029/2004GC000816, 2005 . 
Stein, A. and Stein, S.: Constraints on hydrothermal heat flux through the oceanic lithosphere from global heat flow, Earth Planet. Sci. Lett., 99, 3081-3095, 1994.

Teagle, D. A. H., Alt, J. C., Umino, S., Miyashita, S., Banerjee, N. R., Wilson, D. S., and the Expedition 309/312 Scientists: Expedition 309/312 summary, in: Proceedings of the IODP, 309/312, Integrated Ocean Drilling Program, Texas, USA, 2006.

Tominaga, M. and Umino, S.: Lava deposition history in ODP Hole 1256D: Insights from log-based volcanostratigraphy, Geochem. Geophy. Geosy., 11, https://doi.org/10.1029/2009GC002933, 2010.

Tominaga, M., Teagle, D. A. H., Alt, J. C., and Umino, S.: Determination of the volcanostratigraphy of oceanic crust formed at superfast spreading ridge: Electrofacies analyses of ODP/IODP Hole 1256D, Geochem. Geophy. Geosy., 10, https://doi.org/10.1029/2008GC002143, 2009.

Umino, S.: Reviews of Deep Drilling into Oceanic Crust, J. Geogr., 112, 650-667, 2003.

Umino, S., Obata, S., and Lipman, P. W.: Subaqueous lava flow lobes, observed on ROV KAIKO dives off Hawaii, Geology, 28, 503-506, https://doi.org/10.1130/00917613(2000)28<503:SLFLOO>2.0.CO;2, 2000.
Umino, S., Obata, S., Lipman, P., Smith, J. R., Shibata, T., Naka, J., and Trusdell, F.: Emplacement and inflation structures of submarine and subaerial from Hawaii, in: Hawaiian Volcanoes: Deep Underwater Perspectives, edited by: Takahashi, E., Lipman, P. W., Garcia, M. O., Naka, J., and Aramaki, S., Geophys. Monograph, 128, 85-101, https://doi.org/10.1029/GM128p0065, 2002.

Umino, S., Crispini, L., Tartarotti, P., Teagle, D. A. H., Alt, J. C., Miyashita, S., and Banerjee, N. R.: Origin of the sheeted dike complex at superfast spread East Pacific Rise revealed by deep ocean crust drilling at Ocean Drilling Program Hole 1256D, Geochem. Geophy. Geosy., 9, https://doi.org/10.1029/2007GC001760, 2008.

Umino, S., Nealson, K., Wood, B., Umino, S., Nealson, K., and Wood, B.: Drilling to Earth's mantle, Phys. Today, 66, https://doi.org/10.1063/PT.3.2082, 2013.

Wilson, D. S., Wilson, D. S., Teagle, D. A. H., Alt, J. C., Banerjee, N. R., Umino, S., Miyashita, S., Acton, G. D., Anma, R., Barr, S. R., Belghoul, A., Carlut, J., Christie, D. M., and Coggon, R. M.: Drilling to Gabbro in Intact Ocean Crust, Science, 312, 10161020 https://doi.org/10.1126/science.1126090, 2006. 